which are no longer parallel, you will see that there is a distinct alteration in the effect produced; the beam is directed to another portion of the wall altogether. The ray strikes the first side of the prism, and is bent towards the thicker part, or towards a line perpendicular to this surface, and on reaching the second side of the wedge, the ray is again bent in the same direction towards the base of the prism, for in this case the ray is bent away from the perpendicular to the second surface, and the light emerges from the second surface in a totally new direction. Fig. 7 show's the effect in three cases, the incident ray S I the path in prism I E, and the refracted ray E R; N I and $\mathrm{E} \mathrm{N}^{\prime}$ being the lines perpendicular to the surfaces. An experiment may easily be tried, which will confirm this. Let a triangular piece of glass be held, with one edge pointing upwards, between the eye and a lighted candle, as shown in Fig. 8 ; it will be found that the candle cannot be seen; but if the prism be gradually raised, the image of the candle will appear, the amount the prism will have to be raised depending on its angle. Now, we have here obtained a deviation or refraction of light -that is to say, it has been bent out of its course; for we have to look upwards to see the candle. Another effect has also been produced : the light which was white on entering the prism is now made up of several colours, which are separated more or less from each other; the candle, as seen in the last experiment, is not white, but is fringed round with colours. If we again take our beam of light in the dark room, as in Fig. 9, and allow it to strike on one of our prisms, so placed that its edges are horizontal, and also that the beam enters it obliquely by one of its surfaces, and then receive the image on a screen, we see a band of colours which reminds us strongly of the rainbow : the lowest colour, if the base of the prism be upwards, will be red, next above orange, passing by imperceptible gradations to yellow, and afterwards green, which then passes through the shades of greenish blue till it becomes a pure blue, then indigo, and finally ends with a violet colour. The transition from one colour to another is not abrupt, but is made in an imperceptible manner, so that it can scarcely be said, for instance, where the yellow ends or the green begins. The cause of this band of colours, or spectrum as it is called, was first discovered by Sir Isaac Newton, who tortured this spectrum in several ways. He took one of the colours thus produced, say red, as is shown in the figure, and made it pass through a second prism, receiving the image on a second screen; the image is found to be rather longer, but the colour remains unaltered. This experiment proves that this colour of the spectrum is simple, and the same has been found of all the others. As Newton in his experiment operated with sunlight, the band of colours was in this case called the solar spectrum. The rainbow itself is also in reality nothing more nor less than a solar spectrum, which is caused by refraction in the rain-drops.

If, instead of getting one beam of white light, we take two of differently coloured lights, red and blue, and pass these two beams of different colour through the same prism, you will see that the action of the prism on these two differently coloured beams will be unequal ; in other words, you will get the red beam deflected to a certain distance from a straight line, and the blue deflected to a certain other distance. You see by this experiment that there is a distinct difference in the amount of refrangibility-that the red light is not diverted so far out of its original direction by the prism as the blue. And this leads us to Newton's first proposition, which is this :- "Lights which differ in colour differ in refrangibility." I think that requires no explanation. You will be able to translate it for yourselves thus: Lights which differ in colour are differently acted upon by a prism, which, as you have seen, gives us a considerable result of the action of refraction.

(To be continued.)

\section{THE GEOLOGICAL EXHIBITION IN} GLASGOW

THERE is probably no town or city in the United Kingdom, out of London, in which the science of Geology has been studied more extensively and enthusiastically, and to more purpose, than in Glasgow, during the last fifteen or twenty years. It is about fifteen years since the Geological Society of Glasgow was formed, and during the whole of that period the progress of the study and of the Society has never flagged, of which there was ample evidence afforded by a great exhibition of geological and mineralogical specimens which the Society held in the Corporation Galleries on the evening of Friday, December 6.

The Geological Society of Glasgow is one of the very few provincial societies, the results of whose scientific labours are permanently placed on record, and consulted by geologists elsewhere. The "Transactions" of the Society are now in the fourth volume, and in them there are embodied many valuable original memoirs bearing particularly on special departments of the geology of Lanarkshire and the West of Scotland.

The exhibition of the Society of which we are now giving a brief account, was chiefly devoted to an illustration of the fauna and flora of the Carboniferous system of the west of Scotland. Various members of the Society have worked most successfully in other departments of geological inquiry, but the function of the Society as a whole seems to have been especially the investigation of the Carboniferous system, and the elucidation of the many important physical problems connected therewith; and when we consider the fact that the exhibition in question was only a representation of the geological collections from which the specimens were obtained, we cannot help concluding that the Society's function has been performed with most surprising results to science.

Mr. James Tharnson, F.G.S., corresponding member of the Royal Society of Liège, was certainly the chief ex. hibitor in the department of carboniferous fossils; but he was well supported by Messrs. Young and Armstrong. The first-named gentleman has done immense service during the last fifteen years, as a collector, particularly in connection with the fossil corals. His services in this respect have been extensively acknowledged at homeby the British Association and otherwise-and by Continental and American geologists, museums, \&c. It is probable that, within the time named, Mr. Thomson has made sections of not fewer than ten thousand specimens of his favourite fossil corals. Besides the corals, Mr. Thomson's collection is peculiarly rich in reptilian remains, some of them quite unique and rare. Mr. Armstrong's specimens were generally representative of all the groups of animals and plants contained in the coal, ironstone, shale, and limestone series of the west of Scotland-Lanarkshire and the adjoining counties. Many of his cases excited great admiration. Besides being generally representative of the carboniferous system, Mr. Young was very strong in the Entomostraca and Foraminifera of that system, the species of which he has materially increased by his own discoveries.

In the department of Post-Tertiary shells, Mr. David Robertson, F.G.S., was without a competitor. Indeed, he has been such a devoted student of the Post-Tertiary period, that his collection is probably unrivalled. For a number of years the Rev. H. W. Crossley, F.G.S., now of Birmingham, was a zealous co-worker with Mr. Robertson. The Ostracoda and Foraminifera of the Carboniferous system, and the recent Hydrozoa and Polyzoa, were also largely represented in Mr. Robertson's cases.

Silurian fossils collected in the Girvan district, on the coast of Ayrshire, were shown by Mrs. Robert Gray, an enthusiastic naturalist; and from the Silurian system 
some interesting specimens were exhibited by Mr. Dairon, whose collection was also specially rich in Graptolites from the neighbourhood of Moffat. Mr. Dairon exhibited Liassic fossils from the Whitby district, and Mr. Bell illustrated the Liassic system of the Isle of Skye.

Mr. Wünsch, one of the vice-presidents of the Society, was as strong as any exhibitor of volcanic minerals collected by himself on Vesuvius and Etna, and in the volcanic district of the Auvergne Mountains. The same gentleman showed specimens of the fossilised remains of a primeval forest which he found in association with volcanic ash on the shores of the island of Arran a few years aro.

There is no public museum in Glasgow that is worthy of the name in which these collections could find a home. Overtures have been made, in at least one instance, to secure many of the specimens for museums or for private collections elsewhere. It will afford room for profound regret if the ultimate possession of such collections should be diverted from the west of Scotland, where they have almost entirely been collected. Surely the wealthy corlmasters, ironmasters, shipbuilders, man: facturers, merchants, and others in Glasgow and the surrounding district, are not so supremely devoted to money-getting that they cannot amongst them raise a fund of a few thousand pounds to found a museum, the geological position of which shall have as a nucleus those priceless collections already referred to. Possibly some definite shape may be given to this idea when, in the course of the next few years, the British Associat:on holds its third meeting in Glasgow, on which occasion the Glasgow geclogists will not fail to gratify the longings of their geological friends elsewhere, many of whom have but a faint idea of the intellectual feast which is in store for them.

JOHN MIAYER

\section{THE RISING OF AUSTRALIA}

$\mathrm{O}$

BSERVING that the gradual elevation of the land in the Australian portion of the southern hemisphere is attracting the attention of European geologists, I am induced to forward a few observations thereon, based upon personal investigation.

In March last, in a letter to the editor of this journal, under the title of "Circumpolar Land," Mr. Howorth cites a passage from my paper on the geological structure of this portion of the island, viz., Hobart Town. My remarks upon these post-pliocene evidences of terrestrial elevation were necessarily brief, owing to the various formations treated of in that contribution. I now therefore beg to draw the attention of the readers of NATURE to a few instances, in detail ; for the reason that I am satisfied the question is one that demands the strictest inquiry in the present stage of geological science.

Upon reading a paper before the Royal Society of Tasmania, in November 1864, on these shell deposits as evidence of recent upheaval of the coast, I found the majority of the observers there present regarded them as having originated at the hands of the aborigines; as being, in short, the refuse of their camps. But I then pointed out the fact that there were genera and species of testaceous remains far too small to have been taken by the blacks for the purpose of food. One argument at that time raised against my deductions was the fact that in some instances fragments of charcoal were found associated with the shells. Where this is the case (though the instances known to me are few) I think I shall be able to show that it is to be traced to subsequent drift agency, and has no connection whatever with the fcrmation of these shell beds.

One of the most interesting of these deposits is to be seen at Sandy Bay, an indent of the estuary of the river Derwent, distant from the city two miles. In a bank formed by a road-cutting distarit sixty yaris inland, and forty feet above high-water mark, exists a shell-bed three feet in thickness. The shells have a matrix of dark argillo-arenaceous soil, and beyond being more or less comminuted, $\epsilon$ specially the bivalves, exhibit few traces of geologic I age. Above the shell-bed repo: es a stratum of vegttable soil a few inches thick. The sh+lls rest upon a stratum of brown clay, having no traces of organisms; and that, in turn, reposes on coarsegrained yellow sandstone, 1raversed by veins of marl near its surface. The shells are all of genera and $s_{r}$ ecies now found living in the water only sixty yards in fiont of and below the deposit. They principally consist of Mytilus, Turbo, Trochus, Delphinulus, Vinus, Pcctcn, Ostrea, Patella, Cerethium, and Natica. In this bed a spcon-bowl-shaped fossil bone was found by a labourer employed in making the road, five years ago. A cast of the bone I recertiy forwarded to one of the first osteclogists of the age for identification. I have little doubt, however, that it is a bone of the hyoidal prociss of some Cetacean. It is 2 ? inches in length, by $22^{\mathrm{g}}$ in breadth, and presents no further signs of decay than the associated shells. At the distance of a mile from this spst seaward, there is another shell-deposit which has an average thicl:ness of two feet, re, osing on a basaltic overflow, and which again reposes on an arenaccous yellow clay, thickly perforated by Pholas. These beds are cxposcd in a vertical section of beiwecn thirly and forty feet in height.

Another locality where these evidinces of recent elevition of the coast are plainly secn, is in the Quecn's Domain, on the north eastern boundary of the ciry, and in the immediate vicinity of Gosernne: $t$ House. Hese, st ells are exposed in the surf $c$ ce scil, 500 yalds from the water-line of the estuary, but they are in a firely commir.uted condition. They are thickiy intersfersed through the bec's of the Royal Sociefy's Garders adjoining.

In the district of Lorre', which is fourtcen miles from the last-named locality in an easterly direction, there is a long low sandy llat, whose mean elevaticn above the sea-?evel I estimate at ten feet only. The arcnaceous soil of this plateau is thickly studded for about two square miles with oysier shells, come of them being much larger on the arerage than whit are taken x.ow. This platexu is separated from a cliff of sandstone by an arm of the sca about one mile wide and very shallow. The cliff is about eighty feet high and is known as the Bluff. On the top of this cliff is an extensive deposit of oyster shells corresponding in character to those in the flat below. Now, if a line were drawn from this bed of shells to the deposits referred to aiound Hobart 'Town, it would be fourd to occupy a mean altitude of these beds. The conclusion, I believe, to be arrived at from the fact of the same speci.s of sheils existing at such different levels above the sea as those on the cliff and those on the flat, is that the former are older than the latter, though both without coubt belong to the postpliocene epoch, and that the land has been gradually rising since the shells on the cliff contained their inhabitants up to the present time. That a silting up agency has been in operation with regard to the latter deposit is evident. The oyster shells are these kron'n as the mud oyster here, its habitat being mudbanks. Now they are found dispersed through an incoherent sandy deposit, derived from the erosion of the sandstone formations on the opposite shore. The counter-agency of such silting up is, however, infiritesimally small when compared to the scale on which the land is rising.

I might multiply these instances of recent elevation of the land, did time and space permit, by mentioning numerous other examples round the coast of this island. Leaving Tasmania, and going to the Australian mainland, we find their analogues there. While on a geolcgical visit to New South Wales and Victoria tro jears ago I was struck by the exact represertatiles of the se sta 